\title{
Kompetensi Pengadilan
}

\author{
Alpase Nico \\ alpase.nico@gmail.com \\ 1910003600017 \\ UNIVERSITAS EKASAKTI PADANG
}

\section{A.PENDAHULUAN}

Berbicara mengenai kekuasaan mengadili, maka hal ini berkaitan dengan kompetensi dari badan pengadilan.Suatu gugatan harus diajukan kepada badan peradilan yang benarbenar berwenang untuk mengadili persoalan ini. 3 Hukum acara perdata berlaku dalam pemeriksaan perkara-perkara perdata di pengadilan. Oleh karena itu, berbicara tentang hukum acara perdata tidak akan lepas pada sistem peradilan yang ada di Indonesia.Berdasarkan Pasal 24 UUD 1945, kekuasaan kehakiman dilaksanakan oleh Mahkamah Agung beserta badan peradilan yang ada di bawahnya dan sebuah Mahkamah Konstitusi. Berdasarkan ketentuan- ketentuan UUD 1945, badan peradilan yang ada di bawah Mahkamah Agung meliputi badan peradilan dalam lingkungan:

1. Peradilan Umum;

2. Peradilan Agama;

3. Peradilan Tata Usaha Negara dan

4. Peradilan Militer 
Pemeriksaan perkara di semua badan peradilan berlangsung dalam dua tingkat, yaitu tingkat pertama dan tingkat banding. Pengadilan-pengadilan ini berwenang untuk memeriksa fakta (judex facti). Adapun Mahkamah Agung bukanlah pengadilan tingkat ketiga, karena ia tidak lagi memeriksa fakta melainkan memeriksa penerapan hukum yang dilakukan oleh judex facti sebagai pengadilan yang ada di bawahnya, untuk itu Mahkamah Agung disebut juga sebagai judex juris. Setiap lingkungan peradilan memiliki kompetensi absolut masing-masing. Kompetensi absolut ini menentukan yurisdiksi perkara yang dapat diadili oleh masingmasing lingkungan pengadilan. Lingkungan Peradilan umum (yang dilaksanakan oleh Pengadilan Negeri dan Pengadilan Tinggi), memiliki kompetensi atau kewenangan untuk memeriksa dan mengadili perkara-perkara pidana dan perdata umum. Di samping itu dalam lingkungan Peradilan Umum terdapat pula pengadilan yang memiliki kompetensi khusus, yaitu: 
a. Pengadilan Niaga dengan komptensi memeriksa dan mengadili perkara-perkara kepailitan, penundaan kewajiban pembayaran utang dan sengketa Hak Kekayaan Intelektual;

b. Pengadilan Hubungan Industrial dengan kompetensi memeriksa dan mengadili perselisihan hubungan industrial (sengketa perburuhan);

c. Pengadilan Hak Asasi Manusia (HAM) dengan kompetensi memeriksa dan mengadili perkara pelanggaran HAM berat;

d. Pengadilan Tindak Pidana Korupsi dengan kompetensi memeriksa dan mengadili perkara-perkara tindak pidana korupsi yang disidik dan dituntut oleh Komisi Pemberantasan Tindak Pidana Korupsi.

Penjelasan Atas Undang-Undang Republik Indonesia Nomor 49 Tahun 2009 Tentang Perubahan Kedua Atas Undang-Undang Nomor 2 Tahun 1986 Tentang Peradilan Umum. Undang-Undang Dasar Negara Republik Indonesia Tahun 1945 dalam Pasal24 ayat (1) menegaskan bahwa kekuasaan kehakiman merupakan kekuasaan yang merdeka untuk menyelenggarakan peradilan 
gunamenegakkan hukum dan keadilan.Pasal 24 ayat (2) UndangUndang Dasar Negara Republik Indonesia Tahun1945 menentukan bahwa Kekuasaan Kehakiman dilakukan oleh sebuah Mahkamah Agung dan badan peradilan dibawahnya dalam lingkunganperadilan umum, lingkungan peradilan agama, lingkungan peradilan militer,lingkungan peradilan tata usaha negara, dan oleh sebuah Mahkamah Konstitusi. Undang-Undang Republik Indonesia Nomor 48 Tahun 2009 tentang KekuasaanKehakiman.Pasal 18: Kekuasaan kehakiman dilakukan oleh sebuah Mahkamah Agung dan badan peradilan yang berada dibawahnya dalam lingkungan peradilan umum, lingkungan peradilan agama,lingkungan peradilan militer, lingkungan peradilan tata usahanegara, dan oleh sebuah Mahkamah Konstitusi. 


\section{B.PEMBAHASAN}

\section{Kedudukan Hukum Identitas Domisili}

Status hokum seseorang juga menentukan tempat tinggalnya, sehingga akan menentukan pula hak dan kewajiban menurut hukum. Tempat tinggal seorang istri ditentukan oleh pemufakatan dengan suaminya.Dengan demikian hak dan kewajiban hukum mengikuti tempat tingga yang ditentukan itu.Tempat tinggal anak dibawah umur di tentukan oleh tempat tinggal orangtuanya. Dengan demikian hak dan kewajiban anak tersebut ditentukan oleh tempat tinggal kedua orang tuanya itu. Perjanjian juga menentukan tempat tinggal atau tempat kedudukan.Dengan demikian hak dan kewajiban mengikuti tempat tinggal/alamat yang dipilih sesuai perjanjian.

Arti pentingnya domisili. Arti penting (relevansi) tempat tinggal bagi seseorang atau badan hukum ialah dalam hal pemenuhan hak dan kewajiban, penentuan status hukum seseorang 
dalam lalu lintas hukum, an berusaha dengan pengadilan. Tempat tingggal menentukan apakah seseorang itu terikat untuk memenuhi hak dan kewajibannya dalam setiap peristiwa hukum. Tempat tinggal juga menentukan status hukum seseorang apakah ia dalam ikatan perkawinan, apakah ia dalam keadaan belum dewasa, apakah ia dalam keadaan tidak wenang berbuat. Tempat tinggal juga menentukan apabila seseorang berurusan/berpekara di muka pengadilan.Pengadilan Negeri atau Pengadilan Agama berwenang menyelesaikan perkara perdata adalah yang daerah hukumnya meliputi tempat tinggal tergugat (Pasal 118 HIR).

Domisili penting untuk seseorang dalam hal sebagai berikut :

1. Untuk menentukan atau menunjukan suatu tempat di mana berbagai perbuatan hokum harus dilakukan, misalnya mengajukan gugatan, pengadilan mana yang berwenang mengadili (menurut Sri Soedewi M.Sofwan).

2. Untuk mengetahui dengan siapakah seseorang itu melakukan hubungan hokum serta apa yang menjadi hak dan kewajiban masing-masing (Riduan Syahrani). 
3. Untuk membatasi kewenangan berhak seseorang.

\section{Peranan Identitas Domisili DalamMenentukan Kompetesi Relatif}

4. Kompetensi Absolut

Kompetensi absolut suatu pengadilan telah dikemukakan dalam penjelasan Pasal 10 ayat (1) UU Nomor 14 Tahun 1970 (yang telah diubah beberapa kali) sebagai berikut :

a. Didasarkan pada lingkungan kewenangan.

b. Masing-masing lingkungan memiliki kewenangan mengadili tertentu (diversity jurisdiction).

c. Kewenangan tertentu tersebut menjadi kewenangan absolut (absolute jurisdiction) pada masing-masing lingkungan peradilan sesuai dengan subjek/materinya.

d. Oleh karena itu masing-masing lingkungan pengadilan hanya berwenang mengadili perkara/kasus yg dilimpahkan UU kepadanya.

Secara garis besar, kompetansi absolut 4 lingkungan pengadilan tersebut adalah sebagai berikut : 
1) Peradilan Umum (Pasal 50 dan 51 UU Nomor 2 Tahun 1986 tentang Peradilan Umum), berwenang mengadili perkara : pidana (pidana umum dan khusus) dan perdata (perdata umum dan niaga).

2) Peradilan Agama (Pasal 49 UU Nomor 7 Tahun 1989 sebagaimana diubah dengan UU Nomor 3 Tahun 2006), berwenang mengadili perkara:
a). Perkawinan.
b). Waris
c). Hibah
d). Wakaf
e). Zakat
f). Infaq
g). Shadaqah
h). Ekonomi syari'ah

3) peradilan TUN (Pasal 47 UU Nomor 5 Tahun 1986),berwenang mengadili sengketa TUN 
4) Peradilan Militer (Pasal 40 UU Nomor 31 Tahun 1997), berwenang mengadili perkara pidana dengan terdakwa prajurit TNI.

\section{Kompetensi Relatif.}

Kompetensi relatif merupakan kewenangan pengadilan untuk menangani kasus/perkara yang berkaitan dengan tempat/lokasi/domisili pihak-pihak yang berperkara atau barang yang menjadi objek sengketa. Dengan kata lain, kompetenasi relatif adalah kewenangan pengadilan untuk menangani perkara sesuai dengan wilayah hukum (yurisdiksi teritorial) yang dimilikinya. Asas-asas yang berkaitan dengan kompetensi relatif :

a. Gugatan diajukan di Pengadilan dimana Tergugat berdomisili (Actor sequitur forum rei).

b. Gugatan diajukan di mana benda tetap yang menjadi objek sengketa itu berada (Forum rei sitae).

c. Gugatan diajukan di salah satu pengadilan tempat tinggal Tergugat jika Tergugat lebih dari satu orang. 
d. Gugatan diajukan di salah satu pengadilan yang dipilih/disepakati.

e. Eksepsi pada kompetensi relatif diajukan pada sidang pertama, atau setidak-tidaknya sebelum menggunakan eksepsi lain. Jika waktu eksepsi tersebut telah lewat, maka hakim tidak perlu memperhatikan eksepsi tersebut.

Asas Actor sequitur forum rei sebetulnya merupakan salah satu implementasi dari dari asas Audi et alteram partem (hakim harus memperhatikan kepentingan kedua belah pihak secara adil), karena pada dasarnya gugatan diajukan untuk kepentingan Penggugat yang "belum tentu benar". Oleh karena itu Tergugat yang "belum tentu bersalah" harus dihormati sedemikian rupa dan tidak boleh dipaksa untuk bersusah payah datang ke Pengadilan yang berada di wilayah hukum Penggugat yang bisa jadi jauh dari tempat tinggal Tergugat.

Namun di luar asas tersebut, Pasal 118 ayat (3) HIR memberi hak kepada Penggugat untuk mengajukan gugatan ke 
Pengadilan tempat tinggal Penggugat dengan syarat-syarat yang harus dipenuhi, yakni

a. Apabila tempat tinggal/kediaman Tergugat tidak diketahui.

b. Penerapan ketentuan ini tidak boleh dimanipulasi Penggugat, artinya harus didukung dengan surat keterangan dari pejabat yang berwenang.

Pasal 118 ayat (4) HIR memperbolehkan para pihak dalam perjanjian menyepakati pemilihan domisili pilihan untuk memilih Pengadilan tertentu yang berwenang menyelesaikan sengketa yang mungkin timbul dalam perjanjian.

Dewasa ini, dengan berkembangnya arus globalisasi dan modernisasi yang semakin meluas, maka hubungan antar wilayah pun semakin mudah untuk dilaksanakan, hal ini berlaku pula di bidang perdagangan. Akibatnya, semakin banyak pelaku perdagangan yang menyadari bahwa menjalin hubungan dan kerja sama dengan wilayah lain, baik regional maupun internasional sangatlah penting bagi perkembangan perekonomian, yaitu dengan semakin meningkatkan kerjasama di bidang perdagangan. 
Dengan semakin berkembangnya modernisasi dalam perdagangan tersebut juga mengakibatkan semakin kompleksnya aspekaspek yang berkenaan dengan perdagangan itu sendiri, termasuk mengenai hak dan kewajiban dari pihak penjual maupun pembeli. Untuk itu, pengaturan atas pembagian hak dan kewajiban masing-masing pihak dalam perdagangan mutlak diperlukan demi tercapainya kepastian. Pengaturan tersebut dibuat dalam bentuk perjanjian. Di dalam perjanjian yang dibuat, para pihak dapat bebas untuk menentukan hal-hal yang berkaitan dengan perdagangan yang diperjanjikan tersebut, baik formil maupun materil, misalnya mengenai hak dan kewajiban masing-masing pihak, tata carapembayaran, pilihan domisili para pihak, pilihan hukum serta pilihan pengadilan yang akan memeriksa dan mngadili dalam hal terjadi sengketa di dalam pelaksanaan perjanjian.

Dalam praktiknya, terkadang para pihak sulit untuk menghindari adanya sengketa di dalam pelaksanaan perjanjian tersebut.Hal ini disebabkan perbedaan penafsiran dari pelaksanaan 
perjanjian itu sendiri. Dalam hal terjadinya sengketa dan para pihak tidak menemui kata sepakat dalam penyelesaian perselisihan secara musyawarah, maka salah satu pihak dapat menempuh upaya hukum melalui pengajuan gugatan ke pengadilan negeri yang memiliki kewenangan untuk memeriksa dan mengadili sengketa tersebut.

Dalam hal terjadi sengketa akibat penafsiran perjanjian, PN manakah yang berwenang mengadili perkara tersebut? PN sesuai domisili yang dipilih para pihak dalam perjanjian ataukah PN domisili tergugat?Pilihan domisili dan kewenangan relatif PN. Persetujuan para pihak mengenai pilihan domisili, pada prinsipnya tunduk pada prinsip kebebasan berkontrak (freedom of contract) sebagaimana yang diatur dalam Pasal 1338 KUHPerdata. Dengan demikian, kesepakatan tersebut mengikat kepada para pihak untuk beritikad baik menaati dan melaksanakannya.Namun, apabila merujuk pada ketentuan Pasal 118 ayat (4) HIR, terdapat perkecualian yang membuat ketentuan Pasal 1338 KUHPerdata tersebut menjadi tidak bersifat mutlak. Ketentuan Pasal 118 ayat 
(4) HIR mengatur sebagai berikut: "Bila dengan surat syah dipilih dan ditentukan suatu tempat berkedudukan, maka penggugat, jika ia suka, dapat memasukkan surat gugat itu kepada ketua pengadilan negeri dalam daerah hokum siapa terletak tempat kedudukan yang dipilih itu."

Berdasarkan hal tersebut, dapat ditarik kesimpulan sebagai berikut:

1. Dalam sengketa perdata dimuka hakim, kedua belah pihak yang berperkara, bahkan salah satu pihak berhak dan bebas memilih tempat tinggal lain dari tempat tinggal mereka yang sebenarnya;

2. Hak dan kebebasan memilih itu dituangkan dapat dituangkan dalam bentuk akta otentik maupun di bawah tangan; dan

3. Dalam hal ada pilihan domisili, kepada para pihak tetap terbuka pilihan untuk memilih PN yang disepakati atau memilih PN di tempat mana tergugat bertempat tinggal (actor sequitur forum rei). 
Apabila kita memperhatikan ketentuan Pasal 118 ayat (4) HIR dimaksud, tersirat secara jelas bahwa kesepakatan atas pemilihan domisili para pihak tidak menyingkirkan prinsip kompetensi relatif berdasarkan tempat tinggal tergugat sebagaimana diatur dalam Pasal 118 ayat (1) HIR. Bahkan ketentuan Pasal 118 ayat (1) tersebut lebih unggul tanpa mengurangi kebolehan mengajukan gugatan pada PN menurut pasal-pasal tersebut, atas pilihan penggugat (lihat Yahya Harahap, Hukum Acara Perdata, Jakarta: Sinar Grafika, 2006. Hal. 201). Dalam hal ini, apabila penggugat mau, maka ia dapat memilih kompetensi relatif berdasarkan domisili pilihan atau berdasarkan tempat tinggal tergugat.

Kebebasan memilih kompetensi relative dalam hal terdapat kesepakatan pilihan domisili, berdasarkan Pasal 118 ayat (4) HIR tersebut sepenuhnya berada di tangan penggugat, bukan pada pihak tergugat. Jadi, terserah kepada penggugat untuk menentukan apakah gugatan diajukan kepada PN di daerah hokum tempat tinggal tergugat atau PN yang disepakati. 
Terhadap pilihan penggugat tidak dapat dilakukan eksepsi.Berdasarkan uraian di atas, maka tidak ada dasar hukum bagi tergugat untuk mengajukan eksepsi terhadap kompetensi relatif yang dipilih tergugat.Dalam hal ini, pengadilan harus menolak eksepsi yang demikian.Oleh karena itu, hakim yang bersikap menerapkan kompetensi relatif berdasarkan domisili pilihan secara mutlak bertentangan dengan undang-undang.

Bahwasanya setiap penggugat hendaknya memperhatikan syarat formil gugatan yang satu ini yakni syarat kompetensi.Syarat kompetensi ini ada 2 syarat yakni Kompetensi Absolut (absolute competency) dan Kompetensi Relatip (relative competency). Dari 2 syarat kompetensi tersebut jika diuraikan maka masing-masing uraiannya adalah sebagai berikut :

1. Kompetensi Absolut (absolute competency).

Landasan penentuan kompetensi absolut berpatokan kepada pembatasan yurisdiksi badan-badan peradilan.Setiap badan peradilan telah ditentukan sendiri oleh undang- undang batas kewenangan mengadili yang 
dimilikinya.Pembatasan yurisdiksi masingmasing badan peradilan dapat mengacu kepada berbagai ketentuan perundang-undang. Salah satu contoh dapat dikemukan putusan Mahkamah Agung tanggal 5 Maret 1973 dalam putusan Mahkamah Agung No. 613 K/Sip/1992 yang menyatakan : "gugatan atas penguasaan tanpa harta-harta baitulmal adalah kewenangan ataus yurisprudensi lingkungan peradilan umum, bukan lingkungan peradilan agama sebab yang disengketakan adalah penguasaan tanpa hak, bukan pengurusan harta oleh baitumal" Contoh lain adalah Yurisprudensi Mahkamah Agung No 04 K/AG?1975 tanggal 16 Januari 1980 yang pada pokoknya menyatakan : "sejak berlakunya UU No. 1/1974 Jo. PP No. 9/1975 maka perceraian atas perkawinan yang dilakukan secara Islam menjadi yurisdiksi Peradilan Agama".

Berdasar Pasal 10 Undang-Undang No. 4 Tahun 2004 Tentang Kekuasaan Kehakiman secara jelas dan tegas menyatakan bahwasanya Kekuasaan kehakiman dilakukan 
oleh sebuah Mahkamah Agung dan badan peradilan yang berada di bawahnya, dan oleh sebuah Mahkamah Konstitusi. Badan peradilan yang berada di bawah Mahkamah Agung meliputi badan peradilan dalam lingkungan peradilan umum, peradilan agama, peradilan militer, dan peradilan tata usaha negara.

Masing-masing lingkungan peradilan mempunyai bidang yurisdiksi tertentu.Oleh karena itu, suatu gugatan harus tepat diajukan kepada salah satu lingkungan sesuai dengan bidang hukum yang diperkarakan. Apabali batas yurisdiksi dilanggar maka akan mengakibatkan gugatan menjadi cacat dan peradilan yang menerima akan menyatakan diri Tidak Berwenang Mengadili. Mengenai yurisdiksi tentang arbitrase, saat ini lembaga arbitrasesudah dapat dikatakan sebagai lembaga yang memiliki kewenangan absolut. Hal ini dapat dilihat dari beberapa yurisprudensi Mahkamah Agung sebagai berikut : 
a. Putusan Mahkamah Agung No. 3179 K/Pdt/1984 tanggal 4 Mei 1988:"Apabila dalam perjanjian terpat klausula arbitrase maka Pengadilan Negeri tidak berwenang memeriksa dan mengadili gugatan baik dalam konpensi maupun dalam rekonpensi".

b. Putusan Mahkamah Agung No. 228 K/ Sip/ 1976 tanggal 30 September 1983: "Klausul arbitrase menyangkut kekuasan absolut untuk menyelesaikan sengketa yang timbul dari perjanjian".

2. Kompetensi relatif (relative competency).

Kalau kompetensi absolut didasarkan atas Yurisdiksi mengadili maka komptensi relative didasarkan atas patokan batas kewenangan mengadili berdasarkan kekuasaan daerah hukum.Masing-masing badan peradilan dalam suatu lingkungan telah ditetapkan batas-batas wilayah hukumnya. Landasan penentuan kompetensi relatif suatu peradilan merujukkepada asasasas yang ditentukan pasal 118 HIR jo 142 Rbg Jo 99 Rv, seperti : 
a. Actor Sequatur Forum Rei (forum domicili).Berdasarkan asas actor sequatur forum rei ini maka telah ditentukan bahwasanya batas kewenangan relatif badan peradilan untuk memeriksa suatu sengketa perdata : Yang berwenang mengadili adalah Pengadilan Negeri tempat tinggal tergugat. Oleh karena itu agar gugatan memenuhi syarat kompetensi relative maka gugatan harus diajukan ke Pengadilan Negeri tempat tinggal Tergugat. Gugatan menjadi tidak sah jika diajukan ke Pengadilan Negeri tempat tinggal Tergugat. Yang dimaksud tempat tinggal tergugat adalah tempat tinggal yang berdasarkan KTP, Kartu Keluarga atau surat pajak. Perubahan tempat kediaman setelah gugatan diajukan tidak akan mempengaruhi keabsahan gugatan secara relatif. Hal ini untuk menjamin kepastian hukum dan melindungi kepentingan Penggugat.

b. Actore sequatur Forem rei dengan hak opsi. Apabila pihak tergugat teridiri dari beberapa orang dan masing- masing bertempat tinggal di beberapa wilayah hukum 
Pengadilan Negeri yang berlainan maka hukum memberi hak kepada Penggugat untuk memilih salah satu diantara tempat tinggal para tergugat. Dengan demikian penggugat dapat mengajukan gugatan kepada salah satu Pengadilan negeri yang dianggap paling menguntungkan dan atau yang paling memudahkan baginya dalam pengajuan saksi nantinya. Actor Sequitur forum Rei tanpa hak opsi. Kompetensi relatif dalam hal ini hanya berlaku bagi jenis sengketa hutang piutang dimana ada 3 kedudukan yakni pihak debitur, debitur pokok dan penjamin.Dalam hal ini meskipun tergugat terdiri dari beberapa orang serta tinggal diwilayah hukum Pengadilan Negeri yang berlainan maka sudah seharusnya gugatan diajukan ke Pengadilan Negeri tempat tinggal penjamin (guarantor).

c. Tempat Tinggal Penggugat. Ketentuan yang membolehkan gugatan diajukan ke Pengadilan Negeri tempat tinggal Penggugat merupakan pengecualian asas actor sequatur 
forum rei. Penggugat dapat mengajukan gugatan di Pengadilan Negeri tempat tinggal penggugat sepanjang :

1) tidak diketahui tempat tinggal tergugat,

2) juga tidak diketahu tempat tinggal (diam) sebenarnya.

d. Forum Rei Sitae. Dasar menentukan patokan kompetensi relatif menurut asas forum rei yang diatur pasal 118a ayat 3 HIR jo Pasal 1435 Rbg dan pasal 99 hur a ayat 8 RV adalah objek sengketa yang terdiri dari barang tidak bergerak (real property/ immavable property). Dalam sengketa yang menyangkut barang tidak bergerak maka gugatan harus diajukan ke Pengadilan Negeri ditempat mana barang objek perkara diletakkan.

e. Forum rei Sitae dengan hak opsi. Kalau objek perkara terdiri dari beberapa barang tidak bergerak yang terletak di beberapa daerah hukum Pengadilan negeri maka Penggugat dapat melakukan pilihan, dapat mengajukan gugatan kepada salah satu Pengadilan negeri yang dianggap paling menguntungkan. 
f. Domisili pilihan. Mengenai domisili pilihan, penerapannya berpegang kepada ketentuan pasal 118a. 4 HIR jo Pasal 142 Rbg jo. Pasal 99a. $6 \mathrm{Rv}$ yang mana atas ketentuan tersebut menyatakan bahwa kesepatan atas domisili pihan yang dituangkan dalam suatu perjanjian bersifat alternatif yang artinya dapat diajukan ke pengadilan sesuai dengan domisili yang disepakati. Namun demikian tetap memberi hak bagi Penggugat untuk mengajukan gugatan ke Pengadilan negeri tempat tinggal tergugat. Jadi singkatnya, domisili pilihan, tidak mutlak menyingkirkan patokan actor sequatur forum rei.

Yang dimaksud dengan kekuasaan relative (relative competentie) adalah pembagian kewenangan atau kekuasaan mengadili antar Pengadilan Negeri. Atau dengan kata lain Pengadilan Negeri mana yang berwenang memeriksa dan memutus perkara. Pengertian lain dari kewenangan relatif adalah kekuasaan peradilan yang satu jenis dan satu tingkatan, dalam perbedaannya dengan kekuasaan pengadilan yang sama jenis dan tingkatan. 
Misalnya antara Pengadilan Negeri Bogor dan Pengadilan Negeri Subang, Pengadilan Agama Muara Enim dengan Pengadilan Agama Baturaja.

Dari pengertian di atas maka pengertian kewenangan relatif adalah kekuasaan atau wewenang yang diberikan kepada pengadilan dalam lingkungan peradilan yang sama jenis dan tingkatan yang berhubungan dengan wilayah hukum Pengadilan dan wilayah tempat tinggal/tempat kediaman atau domisili pihak yang berperkara.

Kewenangan Relatif Perkara Gugatan Pada dasarnya setiap gugatan diajukan ke Pengadilan yang wilayah hukumnya meliputi:

a. gugatan diajukan kepada pengadilan yang wilayah hukumnya meliputi wilayah kediaman tergugat. Apabila tidak diketahui tempat kediamannya maka pengadilan dmana tergugat bertempat tinggal;

b. apabila tergugat lebih dari satu orang maka gugatan dapat diajukan kepada pengadilan yang wilayah hukumnya meliputi wilayah salah satu kediaman tergugat; 
c. apabila tempat kediaman tergugat tidak diketahui atau tempat tinggalnya tidak diketahui atau jika tergugat tidak dikenal (tidak diketahui) maka gugatan diajukan ke pengadilan yang wilayah hukumnya meliputi tempat tinggal penggugat;

d. apabila objek perkara adalah benda tidak bergerak, gugatan dapat diajukan kepengadilan yang wilayah hukumnya meliputi letak benda tidak bergerak.

e. Apabila dalam suatu akta tertulis ditentukan domisili pilihan, gugatan diajukan kepada pengadilan yang domisilinya dipilih. 


\section{PENUTUP}

\section{A. KESIMPULAN}

1. Kedudukan hukum identitas domisili menunjukkan pada suatu tempat yang sah sebagai tempat kediaman yang tetap bagi seseorang atau tempat tinggal resmi. Arti pentingnya domisili. Bagi orang atau badan hukum ialah dalam hal pemenuhan hak dan kewajiban, penentuan status dalam setiap peristiwa hokum atau berperkara denganpengadilan. Pengadilan Negeri yang berwenang menyelesaikan perkara perdata adalah yang daerah hukumnya meliputi tempat tinggal tergugat diatur dalam Pasal 118 HIR).

2. Peranan identitas domisili dalam menentukan kompetensi relative menunjukkan bahwa pengadilan negeri di tempat tergugat tinggal mempunyai alamat dan berdomisili yang berwenang memeriksa gugatan dan tuntutan hak. Oleh karena itu kompetensi relative berkaitan dengan wilayah hukum yang berkompetensi mengadili . 


\section{B. SARAN}

1. Kedudukan hukum identitas domisiliperlu dijamin dan dipenuhi pelaksanaanya karena untuk menentukan atau menunjukan suatu tempat di mana berbagai perbuatan hukum harus dilakukan, seperti mengajukan gugatan, pengadilan mana yang berwenang mengadili. Untuk mengetahui dengan siapakah seseorang itu melakukan hubungan hukum serta apa yang menjadi hak dan kewajiban masing-masing danuntuk membatasi kewenangan dari hak seseorang.

2. Peranan identitas domisili dalam menentukan kompetensi relative menunjukkan bahwa suatu gugatan harus diajukan kepada badan peradilan yang benar-benar berwenang untuk mengadili persoalan hukum, karena salah satu eksepsi dalam hukum acara perdata adalah eksepsi mengenai kewenangan mengadili. Eksepsi kewenangan mengadili dapat diajukan apabila dianggap pengadilan tidak berwenang mengadili perkara yang bersangkutan. 


\section{DAFTAR PUSTAKA}

1. Darmini Roza dan Laurensius Arliman S Peran Pemerintah Daerah Di Dalam Melindungi Hak Anak Di Indonesia, Masalah- Masalah Hukum, Volume 47, Nomor 1, 2018.

2. Laurensius Arliman S, Komnas HAM dan Perlindungan Anak Pelaku Tindak Pidana, Deepublish, Yogyakarta, 2015.

3. Laurensius Arliman S, Penguatan Perlindungan Anak Dari Tindakan Human Trafficking Di Daerah Perbatasan Indonesia, Jurnal Selat, Volume 4, Nomor 1, 2016.

4. Laurensius Arliman S, Problematika Dan Solusi Pemenuhan Perlindungan Hak Anak Sebagai Tersangka Tindak Pidana Di Satlantas Polresta Pariaman, Justicia Islamica, Volume 13, Nomor 2, 2016.

5. Laurensius Arliman S, Pelaksanaan Perlindungan Anak Yang Tereksploitasi Secara Ekonomi Oleh Pemerintah Kota Padang, Veritas et Justitia, Volume 2, Nomor 1, 2016.

6. Laurensius Arliman S, Kedudukan Ketetapan MPR Dalam Hierarki Peraturan Perundang-Undangan Di Indonesia, Lex Jurnalica, Volume 13, Nomor 3, 2016.

7. Laurensius Arliman S, Komnas Perempuan Sebagai State Auxialiary Bodies Dalam Penegakan Ham Perempuan Indonesia, Justicia Islamica, Volume 14, Nomor 2, 2017.

8. Laurensius Arliman S, Peranan Pers Untuk Mewujudkan Perlindungan Anak Berkelanjutan Di Indonesia, Jurnal Ilmu Hukum Tambun Bungai, Volume 2, Nomor 2, 2017.

9. Laurensius Arliman S, Mewujudkan Penegakan Hukum Yang Baik Untuk Mewujudkan Indonesia Sebagai Negara Hukum, Jurnal Hukum Doctrinal, Volume 2, Nomor 2, 2017. 
10.Laurensius Arliman S, Participation Non-Governmental Organization In Protecting Child Rights In The Area Of Social Conflict, The 1st Ushuluddin and Islamic Thought International Conference (Usicon), Volume 1, 2017.

11.Laurensius Arliman S, Partisipasi Masyarakat Dalam Pembentukan PerundangUndangan Untuk Mewujudkan Negara Kesejahteraan Indonesia, Jurnal Politik Pemerintahan Dharma Praja, Volume 10, Nomor 1, 2017, https://doi.org/10.33701/jppdp.v10i1.379.

12.Laurensius Arliman S, Peran Komisi Perlindungan Anak Indonesia Untuk Mewujudkan Perlindungan Anak, Jurnal Respublica Volume 17, Nomor 2, 2018.

13.Laurensius Arliman S, Menjerat Pelaku Penyuruh Pengrusakan Barang Milik Orang Lain Dengan Mempertimbangkan Asas Fungsi Sosial, Jurnal Gagasan Hukum, Volume 1, Nomor 1, 2019.

14.Laurensius Arliman S, Ilmu Perundang-Undangan Yang Baik Untuk Negara Indonesia, Deepublish, Yogyakarta, 2019.

15.Laurensius Arliman S, Isdal Veri, Gustiwarni, Elfitrayenti, Ade Sakurawati, Yasri, Pengaruh Karakteristik Individu, Perlindungan Hak Perempuan Terhadap Kualitas Pelayanan Komnas Perempuan Dengan Kompetensi Sumber Daya Manusia Sebagai Variabel Mediasi, Jurnal Menara Ekonomi: Penelitian dan Kajian Ilmiah Bidang Ekonomi, Volume 6, Nomor 2, 2020.

16. Laurensius Arliman S, Pendidikan Kewarganegaraan,

Deepublish, Yogyakarta, 2020.

17.Laurensius Arliman S, Makna Keuangan Negara Dalam Pasal Pasal 23 E Undang-Undang Dasar 1945, Jurnal Lex Librum, Volume 6, Nomor 2 Juni 2020, http://dx.doi.org/10.46839/1ljih.v6i2.151.

18.Laurensius Arliman S, Kedudukan Lembaga Negara Independen Di Indonesia Untuk Mencapai Tujuan Negara Hukum, Kertha Semaya Journal Ilmu Hukum, Volume 8, Nomor 7, 2020. 
19.Laurensius Arliman S, Pelaksanaan Assesment Oleh Polres Kepulauan Mentawai Sebagai Bentuk Pelaksanaan Rehabilitasi Bagi Pecandu Dan Korban Penyalahgunaan Narkotika, Jurnal Muhakkamah, Volume 5, Nomor 1, 2020.

20.Laurensius Arliman S, Aswandi Aswandi, Firgi Nurdiansyah, Laxmy Defilah, Nova Sari Yudistia, Ni Putu Eka, Viona Putri, Zakia Zakia, Ernita Arief, Prinsip, Mekanisme Dan Bentuk Pelayanan Informasi Kepada Publik Oleh Direktorat Jenderal Pajak, Volume 17, No Nomor, 2020.

21.Larensius Arliman S, Koordinasi PT. Pegadaian (Persero) Dengan Direktorat Reserse Narkoba Polda Sumbar Dalam Penimbangan Barang Bukti Penyalahgunaan Narkotika, UIR Law Review, Volume 4, Nomor 2, 2020, https://doi.org/10.25299/uirlrev.2020.vol4(1).3779.

22.Laurensius Arliman S, Tantangan Pendidikan Kewarganegaraan Pada Revolusi 4.0, Ensiklopedia Sosial Review, Volume 2, Nomor 3, 2020.

23. Muhammad Afif dan Laurensius Arliman S, Protection Of Children's Rights of The Islamic And Constitutional Law Perspective Of The Republic Of Indonesia, Proceeding: Internasional Conference On Humanity, Law And Sharia (Ichlash), Volume 1, Nomor 2, 2020.

24.Otong Rosadi danLaurensius Arliman S, Urgensi Pengaturan Badan Pembinaan Idelogi Pancasila Berdasarkan UndangUndang Sebagai State Auxiliary Bodies yang Merawat Pancasila dalam Perspektif Hak Asasi Manusia, Prosiding Konferensi Nasional Hak Asasi Manusia, Kebudayaan dan Tujuan Pembangunan Berkelanjutan Indonesia pada Masa Pandemi Covid19: Tantangan untuk Keilmuan Hukum dan Sosial Volume 1, Universitas Pancasila, Jakarta, 2020. 